\title{
A late Furongian trilobite assemblage from the eastern Cordillera Oriental (Santa Rosita Formation; Jujuy, Argentina) and its biostratigraphic significance
}

\author{
M. Franco TORTELLO ${ }^{1}$ Fernando J. ZEBALLO² \& Daniela S. MONTI ${ }^{3}$
}

\begin{abstract}
${ }^{1}$ CONICET - Universidad Nacional de La Plata, División Paleozoología Invertebrados, Museo de Ciencias Naturales, Paseo del Bosque s-n 1900 La Plata, Argentina.tortello@fcnym.unlp.edu.ar ${ }^{2}$ Museo de Paleontología, Facultad de Ciencias Exactas, Físicas y Naturales, Universidad Nacional de Córdoba, Av. Vélez Sarsfield 299, 5000 Córdoba, Argentina. fzeballo@hotmail.com ${ }^{3}$ CONICET - Universidad de Buenos Aires, Instituto de Ecología, Genética y Evolución de Buenos Aires, Facultad de Ciencias Exactas y Naturales, UBA, Intendente Güiraldes 2160, Ciudad Universitaria, C1428EGA Buenos Aires, Argentina.danielamonti@ege.fcen.uba.ar
\end{abstract}

\begin{abstract}
The trilobite Parabolina frequens argentina Zone is widely represented in the upper Furongian of northwestern Argentina. A fossil assemblage from the lower Santa Rosita Formation at Quebrada de Abra Blanca, Jujuy Province, is described herein. Parabolina frequens argentina (Kayser) and Parabolinella coelatifrons Harrington \& Leanza have previously been reported from other localities of the biozone, whereas Lotagnostus hedini (Troedsson) is here described from South America for the first time. The latter provides high resolution data on the age of the $P$. frequens argentina Zone in the eastern Cordillera Oriental, where conodont-bearing strata have not been found yet. L. hedini exhibits a short biostratigraphic range, restricted to the latest Furongian of China (Xinjiang, Bulbolenus Zone; western Zhejiang, Lotagnostus hedini Zone), Kazakhstan (Euloma limitarisTaoyuania Zone) and ?Canada (western Newfoundland, Phylacterus saylesi Fauna). In China and Kazakhstan, it occurs in association with, or a few meters below, the first appearance of the conodont Cordylodus proavus; a fact that increases the potential for global correlation.
\end{abstract}

Key words: Trilobites, late Furongian, Santa Rosita Formation, Jujuy, Argentina.

Resumen: Una asociación de trilobites del Furongiano tardío del sector este de la Cordillera Oriental (Formación Santa Rosita; Jujuy, Argentina) y su significado bioestratigráfico. La Zona de trilobites de Parabolina frequens argentina está ampliamente representada en el Furongiano superior del noroeste argentino. En este trabajo se describe una asociación fosilífera del tramo inferior de la Formación Santa Rosita aflorante en la Quebrada de Abra Blanca, Provincia de Jujuy. Parabolina frequens argentina (Kayser) y Parabolinella coelatifrons Harrington \& Leanza fueron previamente citados en otras localidades de la biozona, mientras que Lotagnostus hedini (Troedsson) es descripto aquí por primera vez para Sudamérica. Este último taxón aporta datos precisos sobre la edad de la Zona de $P$. frequens argentina en el sector este de la Cordillera Oriental, en donde aún no se han hallado rocas portadoras de faunas de conodontes. Lotagnostus hedini posee un rango bioestratigráfico corto, limitado al Furongiano más tardío de China (Xinjiang, Zona de Bulbolenus; oeste de Zhejiang, Zona de Lotagnostus hedini), Kazakstán (Zona de Euloma limitaris-Taoyuania) y ?Canadá (oeste de Newfoundland, Fauna de Phylacterus saylesi). En China y Kazakstán se registra asociado a, o unos pocos metros por debajo de la primera aparición del conodonte Cordylodus proavus, lo cual incrementa el potencial para realizar correlaciones globales.

Palabras clave: Trilobites, Furongiano tardío, Formación Santa Rosita, Jujuy, Argentina.

\section{INTRODUCTION}

The trilobite Parabolina frequens argentina Zone constitutes an emblematic biostratigraphic unit of the Lower Paleozoic of northwestern Argentina. It was erected by Harrington \& Leanza (1957) for the Cordillera OrientalFamatina and, after some amendments to its original definition, it is currently regarded as late late Cambrian (late Furongian) in age. The unit is principally characterized by olenids and agnostoids, and is widely distributed throughout Jujuy and Salta Provinces (e.g., Harrington \& Leanza, 1957; Esteban \& Tortello, 2007; Waisfeld \& Vaccari, 2008 and references). 
Parabolina frequens argentina (Kayser, 1876) clearly dominates the assemblages of the Biozone, whereas the associated faunas are somewhat variable in different localities. Sections of the western Cordillera Oriental (Lampazar Formation; Sierra de Cajas, Angosto del Moreno, Quebrada deJueya) and the Iruya area (Santa Rosita Formation) contain various genera such as Gymnagnostus, Micragnostus, Pseudorhaptagnostus, Lotagnostus, Parabolinella, Plicatolina, Beltella, Angelina, Akoldinioidia, Asaphellus and Onychopyge (Tortello \& Esteban, 2003; Esteban \& Tortello, 2007, 2009), whereas other localities, especially around the Quebrada de Humahuaca (Santa Rosita Formation; Finca Soledad, Alfarcito, Purmamarca, Punta Corral, Volcán), show lower biodiversity values (Harrington \& Leanza, 1957; Aceñolaza, 1996, unpublished; Zeballo \& Tortello, 2005; Buatois et al., 2006; Zeballo, 2010, unpublished) (Fig. 1.A).

In addition, there are still some outcrops that require further sampling and comprehensive systematic and biostratigraphic studies. In this regard, the Huacalera region is of particular importance (Fig. 1.B). In Quebrada de La Huerta, Manca (1992) reported the occurrence of $P$. frequens argentina in association with fragmentary material of Lotagnostus Whitehouse, 1936, a key fossil of Furongian strata of different continents. In addition, Di Cunzolo (2006) and Zeballo (2010, unpublished) mentioned the presence of $P$. frequens argentina in Quebrada de Abra Blanca, although detailed systematic study was not achieved. Based on new collections, the present paper includes a description of the trilobite assemblages from Quebrada de Abra Blanca and a discussion on their biostratigraphic implications. The material studied provides precise information on the age of the $P$. frequens argentina Zone, which correlates with late Furongian successions of China, Kazakhstan and Canada.

\section{GEOLOGICAL SETTING}

The Cordillera Oriental is a high relief thrust system that is delimited to the east by the Sierras Subandinas and to the west by the Puna. Lower Paleozoic rocks are well represented in the mountain ranges of this geological province, including Cambrian quarzites of the Mesón Group and late Furongian-Early Ordovician shales and sandstones of the Santa Victoria Group (Santa Rosita and Acoite formations and equivalents), which are juxtaposed on Neoproterozoic-early Cambrian slates and meta-graywackes of the
Puncoviscana Formation (e.g., Harrington \& Leanza, 1957; Turner, 1960; Turner \& Mon, 1979; Moya, 1988; Ramos, 1999, 2008; Astini, 2003, 2008).

The Santa Rosita Formation consists of a complex mosaic of late Furongian-late late Tremadocian shales and subordinate sandstones that represent a wide variety of sedimentary environments (Buatois \& Mángano, 2003; Astini, 2003). The unit displays fluvio-estuarine (Tilcara and Pico de Halcón Members), shoreface and offshore sediments (Casa Colorada, Alfarcito, Rupasca and Humacha Members) which accumulated on a gently dipping shelf (Buatois \& Mángano, 2003; Moya et al., 2003; Buatois et al., 2006 and references; Esteban et al., 2015).

The trilobites studied herein come from the discoloured siltstones and shales of the Casa Colorada Member exposed at the Abra Blanca creek (Fig. 2.A, B), about $3 \mathrm{~km}$ southeast of Huacalera village, Jujuy Province (Fig. 1.A, B). There, a 110 m-thick section displays thinly bedded yellowish and light brown shales with intercalations of sandstones, which overlie the sandstones of the Tilcara Member and are overlain by Quaternary deposits.

\section{BIOSTRATIGRAPHIC IMPLICATIONS OF THE FAUNAS}

The assemblage studied is clearly dominated by Parabolina (Neoparabolina) frequens argentina (Kayser, 1876), followed in abundance by Parabolinella coelatifrons Harrington \& Leanza, 1957 and Lotagnostus hedini (Troedsson, 1937). Parabolina frequens argentina is a key taxon of the eponymous zone (cf. Harrington \& Leanza, 1957); a unit that is widely exposed in northwestern Argentina (Esteban \& Tortello, 2007; Waisfeld \& Vaccari, 2008 and references). Although this biozone was originally assigned to the Lower Tremadocian (see Harrington \& Leanza, 1957), subsequent studies confirmed the Cambrian aspect of the strata bearing $P$. frequens argentina, below the first appearance of the trilobite Jujuyaspis keideli Kobayashi, 1936 and the graptolite Rhabdinopora flabelliformis s.l. (Branisa, 1965; Benedetto, 1977; Rushton, 1982, p. 46; Ludvigsen, 1982, p. 150; Aceñolaza, 1983; Salfity et al., 1984; Shergold, 1988, p. 367).

The first evidence of the genus Lotagnostus in the Cordillera Oriental was provided by Manca (1992), who described one cephalon and one fragmentary pygidium (Lotagnostus sp.) associated with Parabolina frequens argentina 


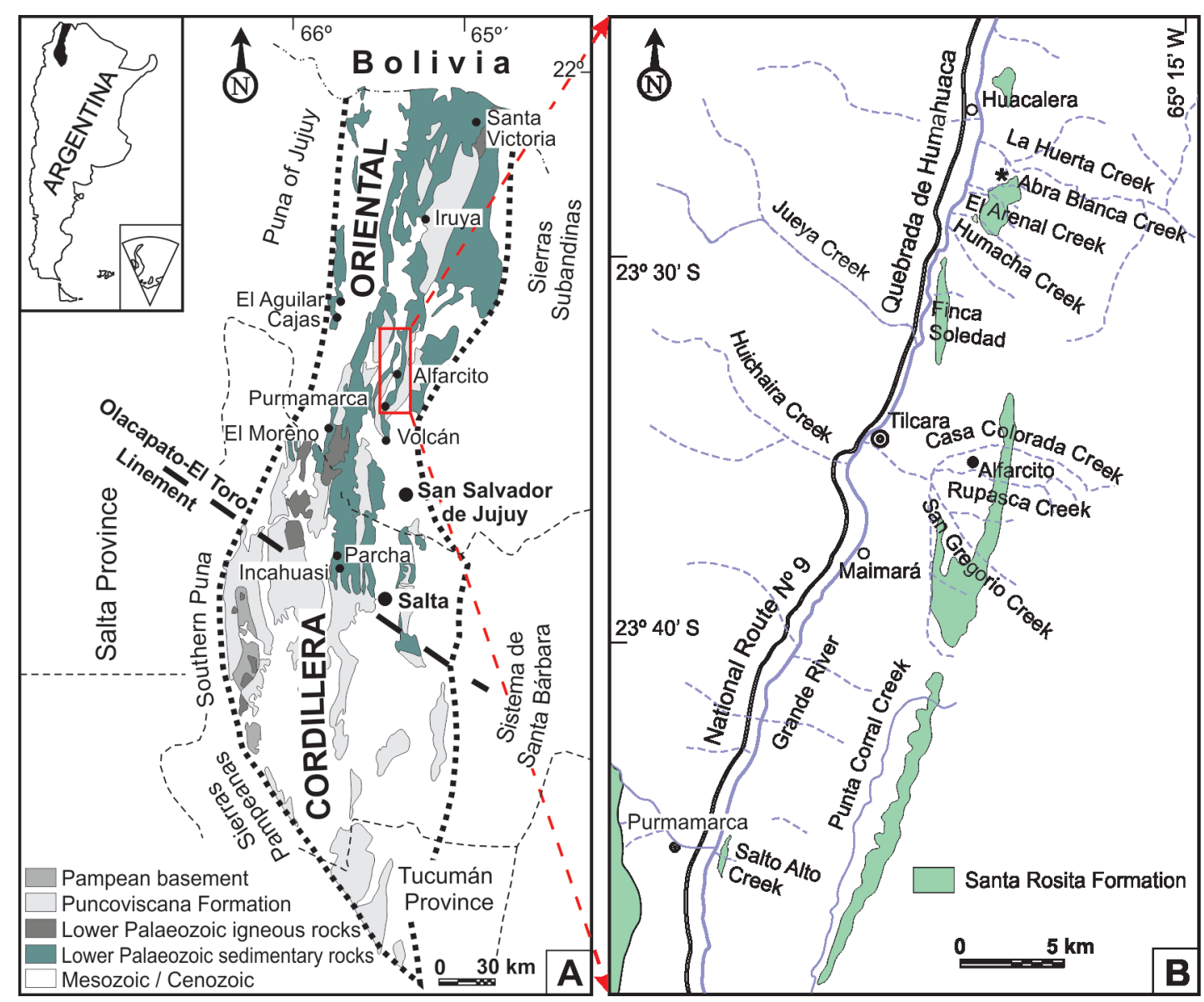

Fig. 1. Location map. A, Cordillera Oriental, northwestern Argentina. B, fossil locality (asterisk).

from Quebrada de la Huerta (Fig. 1). Because Lotagnostus is a cosmopolitan key fossil of late Furongian age, (e.g., Shergold \& Laurie, 1997 and references), its finding in the $P$. frequens argentina Zone provided strong evidence in favor of a pre-Tremadocian age for this unit. Subsequently Esteban \& Tortello (2007) described new material of Lotagnostus (Lotagnostus shergoldi Tortello; L. llamaensis Tortello), associated with $P$. frequens argentina and other species of the biozone, from different localities of the western Cordillera Oriental (Lampazar Formation; Sierra de Cajas, Angosto del Moreno, Quebrada de Jueya).

In addition, studies of conodont faunas supplied more precise information about the age of the $P$. frequens argentina Zone in the Lampazar Formation. At Sierra de Cajas and Angosto del Moreno, $P$. frequens argentina occurs in association with conodonts of the Cordylodus proavus Zone (Hirsutodontus hirsutus Subzone), which include, in particular, C. proavus, C. primiti- vus, C. andresi, Eoconodontus notchpeakensis, Hirsutodontus hirsutus and Proconodontus muelleri (Rao, 1999; Moya et al., 2003; Zeballo \& Albanesi, 2013, fig. 2). Additionally, the lowest Ordovician index fossil Iapetognathus fluctivagus Nicoll, Miller, Nowlan, Repetski and Ethington occurs in the upper part of the overlying Cardonal Formation at Sierra de Cajas, defining the Cambrian-Ordovician boundary in that area (Albanesi et al., 2015).

The record of Lotagnostus hedini (Troedsson, 1937) in the Quebrada de Abra Blanca provides new high resolution data on the age of the Parabolina frequens argentina Zone within the late Furongian. This information is novel for the eastern part (Eastern Belt sensu Astini, 2003) of the Cordillera Oriental (lower Santa Rosita Formation, Casa Colorada Member), where conodont-bearing strata have not been found yet (Zeballo \& Albanesi, 2013). Lotagnostus hedini is one of the youngest species of Lotagnostus 

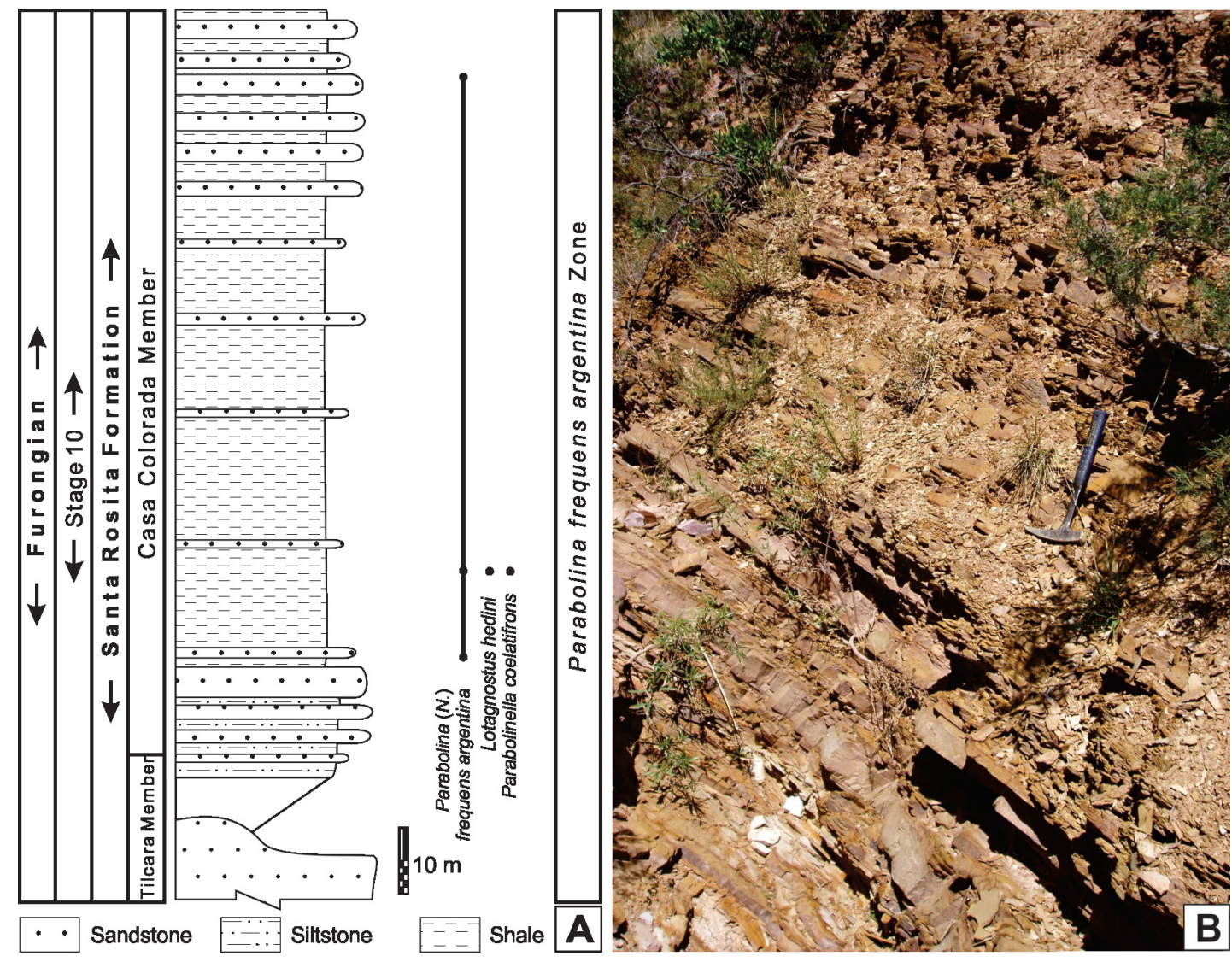

Fig. 2. Lower part of the Santa Rosita Formation at Quebrada de Abra Blanca, Huacalera area, Jujuy. A, stratigraphic section showing distributions of trilobites identified. B, photograph showing part of the outcrop.

and exhibits a short biostratigraphic range, restricted to the latest Furongian. It is known from the Bulbolenus Zone of Xinjiang, Northwest China (Troedsson, 1937), the Lotagnostus hedini Zone of western Zhejiang, China (Lu \& Lin, 1980, 1981, 1983a-c, 1984, 1989), the Euloma limitaris-Taoyuania Zone of the Malyi Karatau Range of Kazakhstan (Apollonov et al., 1984), and, probably, the Phylacterus saylesi Fauna of western Newfoundland (Ludvigsen et al., 1989; see Westrop et al., 2011). In Zhejiang and Kazakhstan, L. hedini is recorded with, or a few meters below, the first appearance (FAD) of Cordylodus proavus.

The occurrence of $L$. hedini in the $P$. frequens argentina Zone is in line with the global upper Cambrian correlation chart of Shergold (1988, fig. 2). Strata with $L$. hedini correlate with the Acerocare Zone of Avalon and the Baltic region. Rushton (1982) and Żylińska (2001) recognized olenid faunas including Parabolina frequens in Wales and Poland, respectively, below the record of the graptolite Rhabdinopora (Rushton, 1982). Fragmentary material of $P$. frequens has also been described from the late Furongian of Mexico (Tiñu Formation), from levels of the Cordylodus proavus Zone (Robison \& Pantoja-Alor, 1968; Landing et al., 2007).

As noted above, the trilobite assemblage of Quebrada de Abra Blanca is completed with Parabolinella coelatifrons. To date, this species is restricted to the $P$. frequens argentina Zone. Type specimens were collected from Cerro Colorado in the Iruya Department in Salta Province, in association with $P$. frequens argentina, the olenid Plicatolina scalpta Harrington \& Leanza, 1957, and the agnostoids Pseudorhaptagnostus (Machairagnostus) tmetus Harrington \& Leanza, 1957 and Micragnostus vilonii Harrington \& Leanza, 1957 (Harrington \& Leanza, 1957). In addition, Parabolinella coelatifrons is part of similar assemblages in Orán, Salta (Harrington \& Leanza, 1957), Iruya, Salta (Esteban \& Tortello, 2009), Sierra de Cajas and Quebrada de Jueya, 
Jujuy (Tortello \& Esteban, 2003; Esteban \& Tortello, 2007).

\section{SYSTEMATIC PALEONTOLOGY}

The material is housed in the Museo de Paleontología, Facultad de Ciencias Exactas, Físicas y Naturales, Universidad Nacional de Córdoba (CORD-PZ), and the Museo de La Plata, Facultad de Ciencias Naturales y Museo, Universidad Nacional de La Plata (MLP). Specimens were whitened with magnesium oxide vapors before photographing. The morphological terms used below have been mostly defined by Robison (1964), Shergold et al. (1990) and Whittington \& Kelly (1997).

Abbreviations: sag sagittally; exs exsagittally.

Order Agnostida Salter, 1864b

Family Agnostidae M'Coy, 1849

Subfamily Agnostinae M`Coy, 1849

Genus Lotagnostus Whitehouse, 1936

Type species. Agnostus trisectus Salter, 1864a.

Remarks. The diagnosis of Lotagnostus was discussed in detail by Shergold \& Laurie (1997 and references) and Westrop et al. (2011). Westrop (1995) and Westrop et al. (2011) regarded the partially effaced taxon Distagnostus Shergold, 1972, as a junior synonym of Lotagnostus, a decision that is accepted herein.

Lotagnostus hedini (Troedsson, 1937) Fig. 3.A, B, E, H

1937. Agnostus hedini sp. nov. Troedsson, p. 20, pl. 1, figs. $6-8$.

2011. Lotagnostus hedini (Troedsson). Westrop, Adrain \& Landing, p. 584, 586 (see for further synonymy).

Material. Three complete specimens and one fragmentary thoracopygon (MLP 35824-35826, CORD-PZ 32189).

Description. Exoskeleton of large size. Cephalon en grande tenue, subcircular to subelliptical in outline in dorsal view, slightly wider than long (maximum width at the posterior part of acrolobe). Glabella long, parallel-sided to gently tapered forward, faintly constricted at F2 and F3, pointed anteriorly, clearly defined by narrow, deep axial furrows, occupying about 73-74\% of cephalic length (sag.); basal lobes large, entire, subtriangular in outline, longer than wide, clearly delimited by conspicuous basal furrows, length (exs.) equal to about 35-40\% of glabellar length (sag.), with anterior tip reaching F2; glabellar rear rounded; F1 almost imperceptible; F2 shallow but better developed than F1, directed inward from the axial furrows and then curved strongly forward exsagittally, delimiting two lateral lobes (M3); median node posterior to the glabellar midpoint, elongate (sag.), better defined posteriorly (between F1 and F2); transglabellar furrow (F3) well-defined, curved forward exsagittally; anteroglabella ogival, occupying about $42-43 \%$ of glabellar length. Gena smooth (Fig. 3.B) or with weak indications of scrobiculation (Fig. 3.E), somewhat narrower (sag.) in front of the glabella; median preglabellar furrow slightly shallower than axial furrows, extending fully from the anterior tip of the glabella to the border furrow. Cephalic border narrow (sag.) and convex, separated from the gena by a well-defined border furrow; sagittally, the border and border furrow combined occupy about 7-8\% of the total length of the cephalon; posterior border with a tiny intergenal spine.

Pygidium en grande tenue, subelliptical in outline in dorsal view, slightly wider than long; axis long, trilobed, slightly constricted at M2, occupying about $85 \%$ of the total pygidial length (excluding articulating half-ring), clearly delimited by narrow, deep axial furrows; M1 and M2 divided into a pair of subquadrate lateral lobes and a central, elongate tubercle; F1 and F2 of similar width and depth, continuous across axis; M3 long, semiovate to ogival in outline, occupying $62-64 \%$ of the total length of the axis (excluding articulating half-ring), smooth or with faint indications of an intranotular axis and a delicate terminal node. Acrolobe gently constricted; pleural fields smooth, confluent, narrower (sag.) behind the axis. Border narrow (sag.) and slightly convex, separated from the pleural fields by a shallow border furrow of variable width; sagittally, the border and border furrow combined occupy about $6-7 \%$ of the total length of the pygidium (excluding articulating half-ring); posterolateral spine vestigial, with base opposite posterior third of axis.

Remarks. The specimens studied are preserved in siliciclastic rocks and are partially compacted, so that they do not exhibit their original convexity. Nevertheless, the state of preservation of the material is quite good. Specimens are characterized by the presence of a proportionately long glabella, a broad V-shaped F3 glabellar furrow, conspicuous basal lobes, a smooth to 
weakly scrobiculate gena, a pygidial F1 that is connected across the axis, a long posteroaxis occupying more than $60 \%$ of the total length of the axis, and a slightly constricted pygidial acrolobe. This combination of characters indicates direct morphological affinities with Lotagnostus hedini (Troedsson, 1937), from the uppermost Cambrian of Xinjiang, Northwest China (Troedsson, 1937, pl. 1, figs. 6-8), western Zhejiang, China ( $\mathrm{Lu} \&$ Lin 1980, pl. 1, figs. 8, 9; 1983a, pl. 1, figs. 5-6; 1983b, pl. 2, figs. 4, 5; 1984, pl. 3, figs. 12, 13; 1989, pl. 7, figs. 4-8), Kazakhstan (Apollonov et al., 1984, pl. 14, figs. 1-8) and, possibly, western Newfoundland (Ludvigsen et al. 1989, pl. 1, figs. 9-11-only-). Westrop et al. (2011, p. 584, 586) provided a diagnosis of $L$. hedini and updated information about its synonymy, distribution and affinities with allied species (see also Peng et al., 2015, p. 299-300). Lotagnostus hedini usually possesses smooth genae, but some specimens from W. Zhejiang (Lu \& Lin, 1983, pl. 2, fig. 4), Kazakhstan (Apollonov et al., 1984, pl. 14, fig. 6) and Argentina (Fig. 3.E) show faint signs of genal scrobiculation. Similarly, the posteroaxis is generally smooth, with the exception of certain cases from China (see Lu \& Lin, 1989, p. 216; Peng et al., 2015) and the Argentinian Cordillera Oriental (Fig. 3.B), which exhibit indications of notular furrows. Intraspecific variability also involves proportions of axial characters. The pygidial axis of small holaspides seems to be a little shorter (sag.) than that of larger specimens (compare Fig. 3.A with Fig. 3.E).

As stated above, Manca (1992) described scarce material of Lotagnostus sp. from Quebrada de La Huerta, consisting of one cephalon and one incomplete pygidium. The latter apparently differs from $L$. hedini in having a discontinuous F1 and a much shorter (sag.) posteroaxis; however, the deficient state of preservation of this specimen prevents a proper comparison. Lotagnostus shergoldi Tortello in Esteban \& Tortello (2007, fig. 8A-I, L) and L. llamaensis Tortello in Esteban \& Tortello (2007, fig. 8J-K, M-Q), from the western Cordillera Oriental, are clearly distinguished from $L$. hedini because the former have a partially effaced exoskeleton, a more anteriorly positioned glabellar node, a discontinu- ous F1 pygidial furrow, an unconstricted pygidial acrolobe, and a border lacking posterolateral spines. Lotagnostus shergoldi has, in addition, a less constricted pygidial M2, and L. llamaensis exhibits a semicircular cephalon and a more delicate pygidial axial node.

Lotagnostus hedini is similar to L. peladensis (Rusconi, 1951), from the upper Furongian of the Argentine Precordillera (e.g., Shergold et al., 1995, pl. 1, figs. 1-9; Tortello, 2014, figs. 2.1$2.28,3.1-3.7)$, but the exoskeleton of the latter differs by having variably effaced dorsal furrows, a proportionately shorter (sag.) pygidial axis, and a pygidial $\mathrm{F} 1$ that is not continuous across the axis. Another species from the Precordillera, $L$. atenuatus (Rusconi, 1955), is also distinguished by its discontinuous pygidial $\mathrm{F} 1$ and, also, by its relatively shorter glabella, pygidial axis and posteroaxis (Westrop et al., 2011; Tortello, 2018). As indicated by Westrop et al. (2011) and Peng et al. (2015, p. 299-300), the transaxial F1 furrow and the large size of the pygidial axis are two of the most diagnostic characters of L. hedini.

Order Ptychopariida Swinnerton, 1915

Suborder Olenina Burmeister, 1843

Family Olenidae Burmeister, 1843

Subfamily Oleninae Burmeister, 1843

Genus Parabolinella Brøgger, 1882

Type species. Parabolinella limitis Brøgger, 1882.

Parabolinella coelatifrons Harrington \& Leanza, 1957

Fig. 3.C, D, F, G, I-L

1957 Parabolinella coelatifrons sp. nov. Harrington \& Leanza, p. 109, fig. 39.3a, b, d-f, h (non fig. 39.3c, g).

2007 Parabolinella coelatifrons Harrington \& Leanza.

Esteban \& Tortello, p. 49, fig. 11B-D, L (top) (see for further synonymy).

2009 Parabolinella cf. coelatifrons Harrington \& Leanza. Esteban \& Tortello, p. 148, fig. 11.C, D, H, J.

Fig. 3. (Next page) Trilobites from the Parabolina frequens argentina Zone of Quebrada de Abra Blanca, Huacalera area, Jujuy. A, B, E, H, Lotagnostus hedini (Troedsson, 1937); A, fragmentary exoskeleton, MLP 35825; B, complete specimen, CORD-PZ 32189; E, complete specimen, MLP 35824; H, pygidium and fragmentary thorax, latex mould, MLP 35826. C, D, F, G, I-L, Parabolinella coelatifrons Harrington \& Leanza, 1957; C, complete specimen, CORD-PZ 32182; D, fragmentary cranidium and thorax, MLP 35827; F, complete specimen, CORD-PZ 32190a; G, cephalon and fragmentary thorax, CORD-PZ 32153; I, cranidium and fragmentary thorax, CORD-PZ 32173; J, complete specimen, MLP 35828; K, axial shield, MLP 35831; L, cranidium, MLP 35829. 

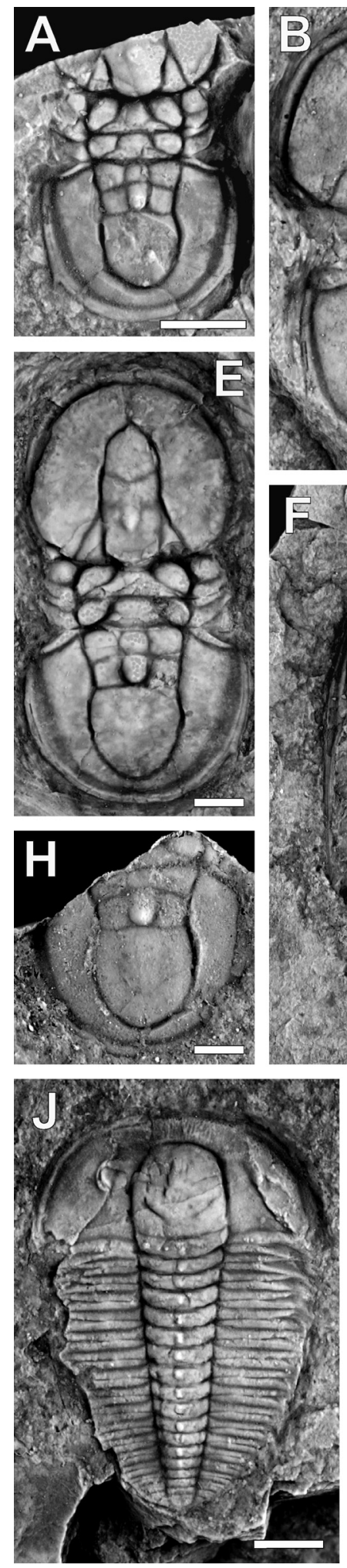
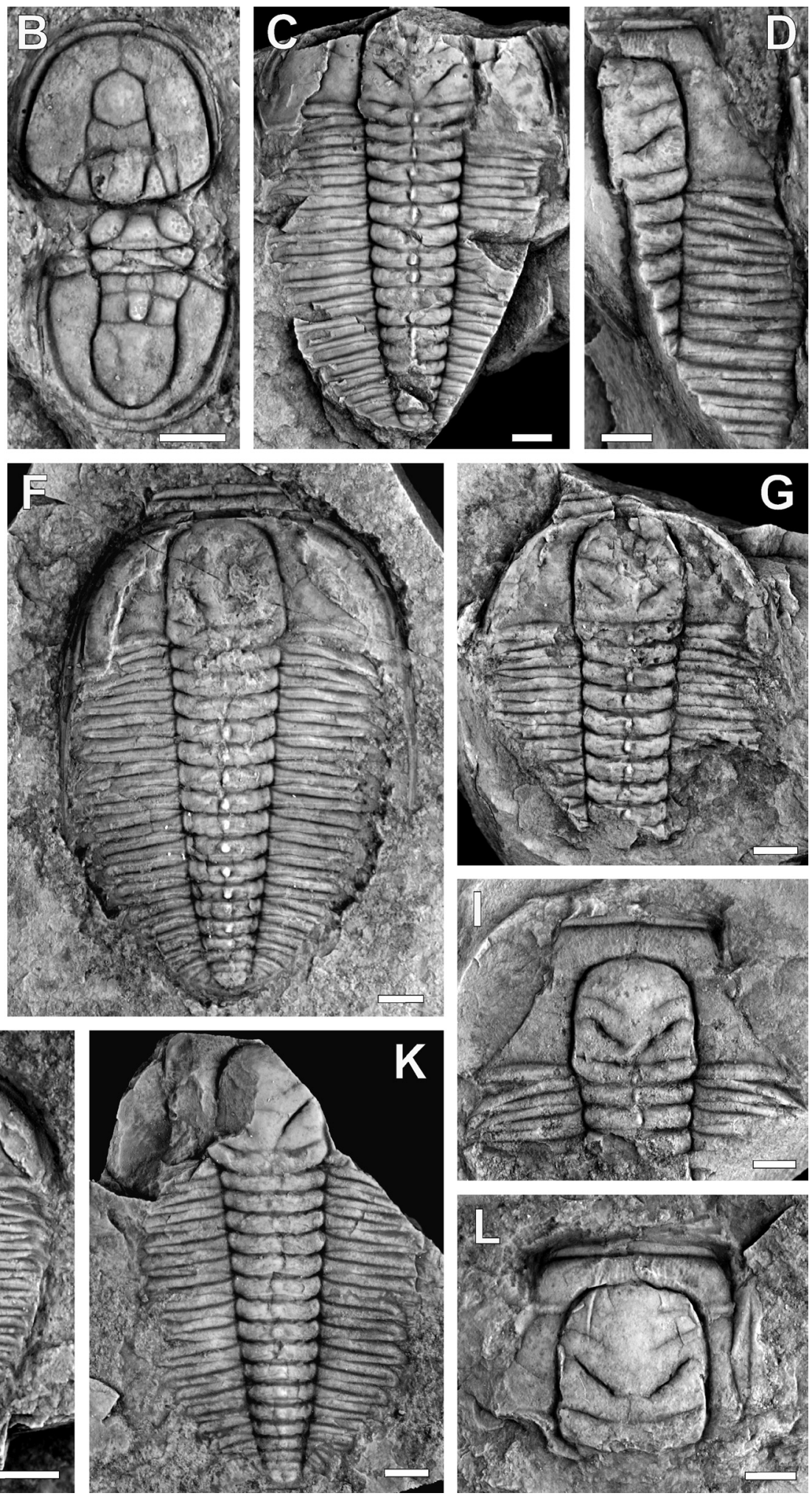
Material. Five complete specimens, four cephala and thoraces, one cranidium, one cranidium and fragmentary thorax, two axial shields and one thoracopygon (CORD-PZ 32153, 32156, 32171, 32173, 32182, 32187, 32190, 32440a; MLP 35827-35832).

Remarks. Parabolinella coelatifrons Harrington \& Leanza is well represented in the Parabolina frequens argentina Biozone (Harrington \& Leanza, 1957; Tortello \& Esteban, 2003; Esteban $\&$ Tortello, 2007). This species is characterized by the presence of a well-developed, faintly striated preglabellar field; a sub-squared glabella having three pairs of lateral glabellar furrows; a facial suture with sub-parallel anterior branches and straight posterior branches, defining sub-triangular fixigenae; and a pygidium with two axial rings. Specimens from Quebrada de Abra Blanca combine all of these characters, but also display some intraspecific variability which broadens the scope of $P$. coelatifrons. Variations involve the degree of development of the preglabellar field (Fig. 3.I, L), the shape of the anterior glabellar margin (Fig. 3.D, G, J), and the width of the posterior margin of the fixigenae (Fig. 3.D, F, I).

Esteban \& Tortello (2009, fig. 11.C, D, H, J) assigned to Parabolinella cf. coelatifrons several cranidia from the Iruya area, pointing out that their preglabellar furrows are more curved than those of the typical representatives of $P$. coelatifrons. However, according to the variability reported above, these cranidia are now regarded confidently as belonging to this species.

Some specimens from Quebrada de Abra Blanca show the librigenae displaced backwards below the axial shield (Fig. 3.C, F, G). This configuration is common among olenids (e.g. Henningmoen, 1957; Clarkson et al., 2003; Tortello \& Clarkson, 2003) and is interpreted as the result of the molting process (Harrington, 1959; Henningsmoen, 1975).

\section{Genus Parabolina Salter, 1849}

Type species. Entomostracites spinulosus Wahlenberg, 1818.

\section{Parabolina (Neoparabolina) Nikolaisen \& Henningsmoen, 1985}

Type species. Parabolina frequens (Barrande, 1868).

Parabolina (Neoparabolina) frequens (Barrande, 1868)
Parabolina (Neoparabolina) frequens argentina (Kayser, 1876)

Fig. 4.A-K

Synonymy. See Tortello \& Clarkson (2008) and references therein.

Material figured. One complete specimen, one cephalon, three cephala and thoraces, two axial shields, and five thoraces and pygidia (CORD-PZ 32152, 32163b, 32176, 32177a, 32192a,b; MLP 35833-35837).

Remarks. Parabolina frequens argentina is an emblematic late Cambrian trilobite of northwestern Argentina and southern Bolivia (Harrington \& Leanza, 1957; Waisfeld \& Vaccari, 2003). As stated by Harrington \& Leanza (1957) and Tortello \& Clarkson (2008), this olenid exhibits a relatively high morphologic variability. In the material from Quebrada de Abra Blanca, variations are especially evident in the width (sag.) of the cephalic anterior border (Fig. 4.A, G), and the degree of expression of the thoracic axial nodes, which are better developed in small adults (e.g., compare Fig. 4.F with Fig. 4.K). It is interesting to note that some late holaspid specimens studied herein reach large sizes (largest observed exoskeleton -excluding $12^{\text {th }}$ thoracic axial spine-: $43 \mathrm{~mm}$ in length).

\section{ACKNOWLEDGEMENTS}

We thank Gladys Ortega, Guillermo Albanesi, Susana Esteban and Eric Hasselrot for assistance in the field. Thejournal reviewers, Adrian Rushton and Steve Westrop, made valuable comments on the manuscript. Financial support was provided by the Consejo Nacional de Investigaciones Científicas y Técnicas (CONICET), the Instituto Superior de Correlación Geológica (CONICET - Universidad Nacional de Tucumán) and the Universidad Nacional de La Plata, Argentina.

\section{REFERENCES}

Aceñolaza, F.G. 1983. The Tremadocian beds and the Cambrian-Ordovician boundary problems in Latin America. In: Papers for the Symposium on the Cambrian-Ordovician and Ordovician-Silurian Boundaries, pp. 88-93, Nanjing Institute of Geology and Palaeontology, Academia Sinica, Nanjing.

Aceñolaza, G.F. 1996. Bioestratigrafía del límite Cámbrico-Ordovícico y Ordovícico basal en la quebrada de Humahuaca, Provincia de Jujuy, Argentina. Tesis Doctoral, Facultad de Ciencias 

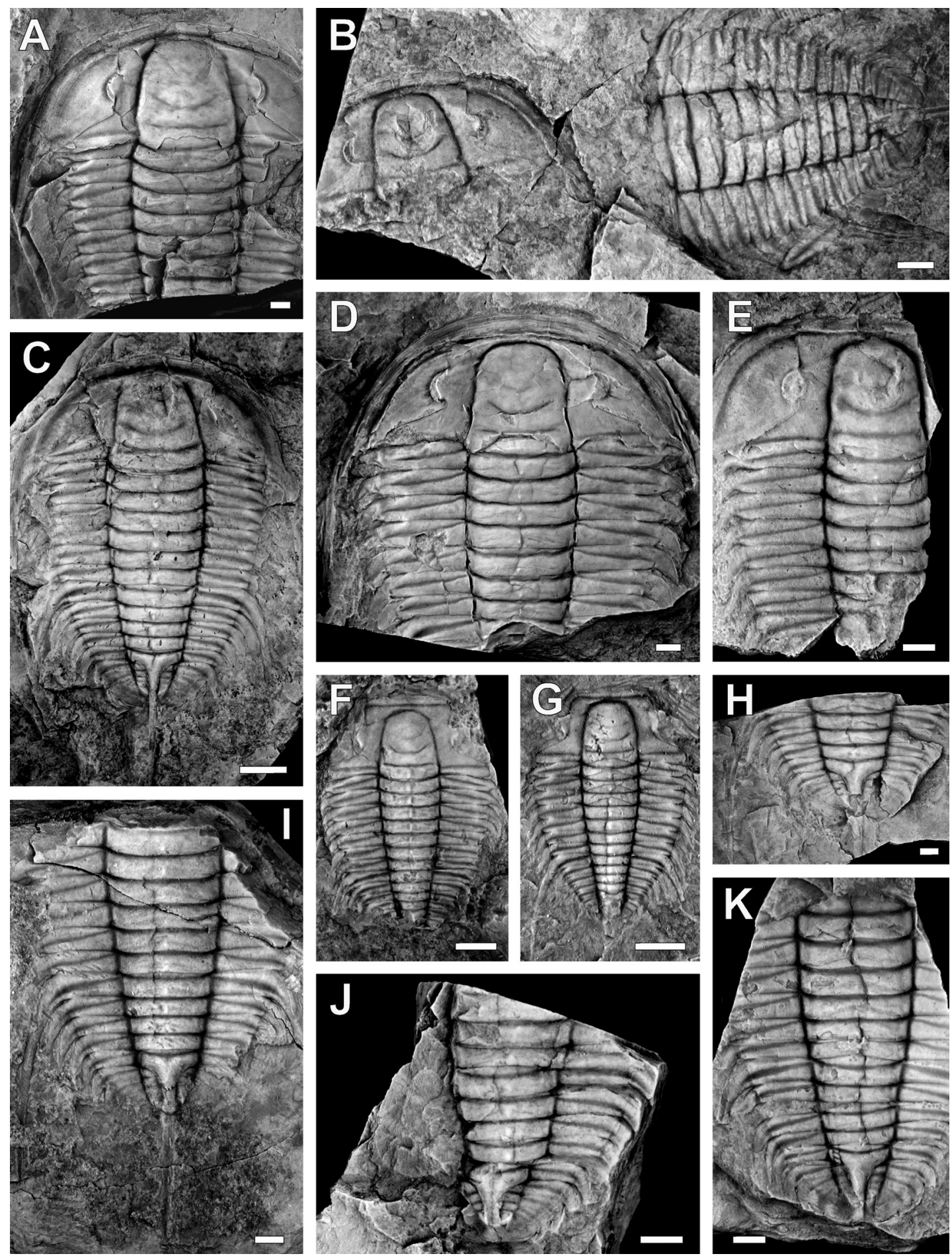

Fig. 4. Trilobites from the Parabolina frequens argentina Zone of Quebrada de Abra Blanca, Huacalera area, Jujuy. A-K, Parabolina (Neoparabolina) frequens argentina (Kayser, 1876); A, cephalon and fragmentary thorax, CORDPZ 32192a; B, cephalon (left) and thoracopygon (right), CORD-PZ 32176; C, complete specimen, CORD-PZ 32177a D, cephalon and fragmentary thorax, CORD-PZ 32152; E, fragmentary cephalon and thorax, MLP 35834; F, small axial shield, MLP 35837; G, small axial shield, MLP 35836; H, fragmentary thoracopygon, CORD-PZ 32192b; I, thoracopygon, MLP 35833; J, fragmentary thoracopygon, CORD-PZ 32163b; K, thoracopygon, MLP 35835. 
Naturales e Instituto Miguel Lillo, Universidad Nacional de Tucumán, 237 pp.

Albanesi, G.L., M.E. Giuliano, F.E. Pacheco, G. Ortega \& C.R. Monaldi. 2015. Conodonts from the CambrianOrdovician boundary in the Cordillera Oriental, NW Argentina. Stratigraphy 12: 237-256.

Apollonov, M.K., M.N. Chugaeva \& S.V. Dubinina. 1984. Trilobites and conodonts from the Batyrbay section (uppermost Cambrian-Lower Ordovician) in Maly Karatau Range (atlas of the palaeontological plates). Nauka, Alma-Ata, 48 pp. [In Russian]

Astini, R.A. 2003. The Ordovician Proto-Andean Basins. In: J.L. Benedetto (ed.), Ordovician fossils of Argentina, pp. 1-74, Universidad Nacional de Córdoba, Secretaría de Ciencia y Tecnología, Córdoba.

Astini, R.A. 2008. Sedimentación, facies, discordancias y evolución paleoambiental durante el CambroOrdovícico. In: B. Coira \& E.O. Zappettini (eds.), Geología y Recursos Naturales de la Provincia de Jujuy. Relatorio del $17^{\circ}$ Congreso Geológico Argentino, pp. 50-73, Asociación Geológica Argentina.

Barrande, J. 1868. Faune Silurienne des environs de Hof, en Baviere. Prague, pp. 31-110.

Benedetto, J.L. 1977. Algunas consideraciones acerca de la posición del límite Cámbrico-Ordovícico en América del Sur. Geos 23: 3-11.

Branisa, L. 1965. Los fósiles guía de Bolivia. I: Paleozoico. Boletín del Servicio Geológico de Bolivia 6: 1-282.

Brøgger, W.C. 1882. Die Silurischen Etagen 2 und 3 im Kristianiagebiet und auf Eker. Universitäts Programm für 2 Semester 1882, Kristiania, 376 pp.

Buatois, L.A. \& M.G. Mángano. 2003. Sedimentary facies, depositional evolution of the Upper CambrianLower Ordovician Santa Rosita Formation in northwest Argentina. Journal of South American Earth Sciences 16: 343-363.

Buatois, L.A., F.J. Zeballo, G.L. Albanesi, G. Ortega, N.E. Vaccari \& M.G. Mángano. 2006. Depositional environments and stratigraphy of the upper Cambrianlower Ordovician Santa Rosita Formation at the Alfarcito area, Cordillera Oriental, Argentina: integration of biostratigraphic data within a sequence stratigraphic framework. Latin American Journal of Sedimentology and Basin Analysis 13: 1-29.

Burmeister, H. 1843. Die Organisation der Trilobiten, aus ihren lebenden Verwandten entwickelt; nebst einer systematischen übersicht aller zeither beschriebenen Arten. Reimer, Berlin, $147 \mathrm{pp}$.

Clarkson, E.N.K., J. Ahlgren \& C.M. Taylor. 2003. Structure, ontogeny, and moulting of the olenid trilobite Ctenopyge (Eoctenopyge) angusta Westergård, 1922 from the Upper Cambrian of Västergötland, Sweden. Palaeontology 46: 1-27.

Di Cunzolo, S.C. 2006. Bioestratigrafía de la quebrada de Abra Blanca (Cámbrico-Ordovícico), Cordillera Oriental argentina. $9^{\text {o }}$ Congreso Argentino de Paleontología y Bioestratigrafía, Resúmenes: 156.

Esteban, S.B. \& M.F. Tortello. 2007. Latest Cambrian sedimentary settings and trilobite faunas from the western Cordillera Oriental, Argentina. Memoirs of the Association of Australasian Palaeontologists 34: 431-460.

Esteban, S.B. \& M.F. Tortello. 2009. Sedimentología y paleontología de la Formación Santa Rosita (Miembros Tilcara y Casa Colorada, Cámbrico Tardío) en la región de Iruya, provincia de Salta. Acta Geológica Lilloana 21(2): 129-153.

Esteban, S.B., M.H. Benítez \& M.F. Tortello. 2015. Geología sedimentaria y paleoambientes de la Formación Santa Rosita (Ordovícico Temprano) en la región de Nazareno, Cordillera Oriental, provincia de Salta, Argentina. Serie Correlación Geológica 31(1): 5-20.

Harrington, H.J. 1959. General description of Trilobita. In: R.C. Moore (ed.), Treatise on Invertebrate Paleontology, Part O. Arhtropoda 1, pp. 38-117. Lawrence.

Harrington, H.J. \& A.F. Leanza. 1957. Ordovician trilobites of Argentina. Department of Geology, University of Kansas Special Publication 1: 1-276.

Henningmoen, G. 1957. The trilobite family Olenidae, with description of Norwegian material and remarks on the Olenid and Tremadocian Series. Skrifter Utgitt av det Norske Videnskaps-Akademi i Oslo, I, Matematisk-naturvidenskapelig Klasse 1957 (1): 1-303.

Henningsmoen, G. 1975. Moulting in trilobites. Fossils and Strata 4: 179-200.

Kayser, E. 1876. Über primordiale und untersilurische Fossilien aus der Argentinischen Republik. Palaeontographica, Supplementum 3, Lieferung 2, Theil II.

Kobayashi, T. 1936. On the Parabolinella fauna from Province Jujuy, Argentina, with a note on the Olenidae. Japanese Journal of Geology and Geography 13: 85-102.

Landing, E., S.R. Westrop \& J.D. Keppie. 2007. Terminal Cambrian and lowest Ordovician succession of Mexican West Gondwana: biotas and sequence stratigraphy of the Tiñu Formation. Geological Magazine 144: 909-936.

Lu, Y-H. \& H-L. Lin. 1980. Cambrian-Ordovician boundary in western Zhejiang and the trilobites contained therein. Acta Palaeontologica Sinica 19: 118-135. [In Chinese].

Lu, Y-H. \& H-L. Lin. 1981. Zonation of Cambrian faunas in western Zhejiang and their correlation with faunas in North China, Australia, and Sweden. II International Symposium on the Cambrian System, Short Paper, pp. 118-120.

Lu, Y-H. \& H-L. Lin. 1983a. Uppermost Cambrian and lowermost Ordovician trilobites of JiangshanChangshan area. In: Papers for the CambrianOrdovician boundaries, pp. 6-11, Academia Sinica, Nanjing.

Lu, Y-H. \& H-L. Lin. 1983b. Zonation and correlation of Cambrian Faunas in WZhejiang. Acta Geologica Sinica 4: 317-328.

Lu, Y-H. \& H-L. Lin. 1983c. Cambrian-Ordovician boundary of Jiangshan-Changshan area. In: Papers 
for the Cambrian-Ordovician boundaries, pp. 1-5, Academia Sinica, Nanjing.

Lu, Y-H. \& H-L. Lin. 1984. Late Cambrian and earliest Ordovician trilobites of Jiangshan-Changshan area, Zhejiang. In: Nanjing Institute of Geology and Palaeontology (ed.), Stratigraphy and Palaeontology of Systemic Boundaries in China, Cambrian-Ordovician Boundary, volume 1, pp. 45-143, Anhui Science and Technology Publishing House, Hefei.

Lu, Y-H. \& H-L. Lin. 1989. The Cambrian trilobites of western Zhejiang. Palaeontologica Sinica, Whole Number 178, New Series B, 25: 1-278. [In Chinese with abstract in English]

Ludvigsen, R. 1982. The Cambrian-Ordovician boundary in the western District of Mackenzie, Canada. In: M.G. Basset \& W.T. Dean (eds.), The CambrianOrdovician boundary: sections, fossil distributions, and correlations, pp. 141-153, National Museum of Wales, Geological Series 3.

Ludvigsen, R., S.R. Westrop \& C.H. Kindle 1989. Sunwaptan (Upper Cambrian) trilobites of the Cow Head Group, western Newfoundland, Canada. Palaeontographica Canadiana 6: 1-175.

Manca, N. 1992. El género Lotagnostus (Trilobita, Agnostida) en la Formación Santa Rosita (Jujuy, Argentina) y su significado cronológico. Ameghiniana 29: 45-48.

M'Coy, F. 1849. On the classification of some British fossil Crustacea with notices of some new forms in the University Collection at Cambridge. Annals and Magazine of Natural History, series 2, 4: 161179, 330-335, 392-414.

Moya, M.C. 1988. Lower Ordovician in the Southern part of the Argentine Eastern Cordillera. Lecture Notes in Earth Sciences 17: 55-69.

Moya, M.C., S. Malanca, J.A. Monteros, G.L. Albanesi, G. Ortega \& L.A. Buatois. 2003. Late CambrianTremadocian faunas and events from Angosto del Moreno section, Eastern Cordillera, Argentina. Serie Correlación Geológica 17: 439-444.

Nikolaisen, F. \& G. Henningsmoen. 1985. Upper Cambrian and lower Tremadoc olenid trilobites from the Digermul peninsula, Finmark, northern Norway. NGU Norges Geologiske Undersokelse Bulletin 400: 1-49.

Peng, S., L.E. Babcock, X. Zhu, P. Ahlberg, F. Terfelt $\&$ T. Dai. 2015. Intraspecific variation and taphonomic alteration in the Cambrian (Furongian) agnostoid Lotagnostus americanus: new information from China. Bulletin of Geosciences 90: 281-306.

Ramos, V.A. 1999. Las provincias geológicas del territorio argentino. In: R. Caminos (ed.), Geología Argentina, pp. 41-96, Instituto de Geología y Recursos Minerales, Anales 29(3), Buenos Aires.

Ramos, V.A. 2008. The basement of the Central Andes: The Arequipa and Related Terranes. Annual Review of Earth and Planetary Sciences 36: 289-324.

Rao, R.I. 1999. Los conodontes Cambro-Ordovícicos de la sierra de Cajas y del Espinazo del Diablo, Cordillera Oriental, República Argentina. Revista
Española de Micropaleontología 31: 23-51.

Robison, R.A. 1964. Late middle Cambrian faunas from western Utah. Journal of Paleontology 38: $510-566$.

Robison, R.A. \& J. Pantoja-Alor. 1968. Tremadocian trilobites from the Nochixtlán region, Oaxaca, Mexico. Journal of Paleontology 42: 767-800.

Rusconi, C. 1951. Trilobitas cámbricos del Cerro Pelado (Mendoza). Boletín Paleontológico de Buenos Aires 24: $1-4$.

Rusconi, C. 1955. Más fósiles cámbricos y ordovícicos de San Isidro, Mendoza. Boletín Paleontológico de Buenos Aires 31: 1-4.

Rushton, A.W.A. 1982, The biostratigraphy and correlation of the Merioneth-Tremadoc Series boundary in North Wales. In: M.G. Basset \& W.T. Dean (eds.), The Cambrian-Ordovician boundary: sections, fossil distributions, and correlations, pp. 41-59, National Museum of Wales, Geological Series 3.

Salfity, J.A., S. Malanca, M.C. Moya, C.R. Monaldi \& E.M. Brandán. 1984. El límite Cámbrico-Ordovícico en el norte de la Argentina. $9^{\circ}$ Congreso Geológico Argentino, Actas 1: 568-575.

Salter, J.W. 1849. Figures and descriptions illustrative of British organic remains, Decade II. Memoirs of the Geological Survey of the United Kingdom: $1-38,10$ pls.

Salter, J.W. 1864a. Figures and descriptions illustrative of British organic remains. Decade XI. Memoirs of the Geological Survey of the United Kingdom: $1-11$.

Salter, J.W. 1864b. A monograph of the British trilobites from the Cambrian, Silurian and Devonian formations. Monograph of the Palaeontographical Society: $1-80$, pls. $1-6$.

Shergold, J.H. 1972. Late Upper Cambrian trilobites from the Gola Beds, western Queensland. Australian Bureau of Mineral Resources, Geology and Geophysics Bulletin 112: 1-127.

Shergold, J.H. 1988. Review of the trilobite biofacies distributions at the Cambrian-Ordovician boundary. Geological Magazine 125: 363-380.

Shergold, J.H. \& J.R. Laurie. 1997. Agnostina. In: R.L. Kaesler (ed.), Treatise on Invertebrate Paleontology, Part O, Arthropoda 1. Trilobita, Revised, pp. 331383, Geological Society of America and University of Kansas Press.

Shergold, J.H., J.R. Laurie \& X. Sun. 1990. Classification and review of the trilobite Order Agnostida Salter, 1864: an Australian perspective. Bureau of Mineral Resources, Geology and Geophysics, Report 296: 1-93.

Shergold, J.H., O.L. Bordonaro \& E. Liñán. 1995. Late Cambrian agnostoid trilobites from Argentina. Palaeontology 38: 241-257.

Swinnerton, H.H. 1915. Suggestions for a revised classification of trilobites. Geological Magazine, Series 6, 2: 487-496, 538-545.

Troedsson, G.T. 1937. On the Cambro-Ordovician faunas of western Quruq Tagh, eastern Tien-Shan. Palaeontologia Sinica 2: 1-74.

Tortello, M.F. 2014. A systematic revision of the late 
Furongian trilobites from Cerro Pelado, Mendoza, Argentina. Ameghiniana 51: 291-310.

Tortello, M.F. 2018. Redescription of a LotagnostusMendoparabolina faunule (Trilobita; late Furongian) from Quebrada San Isidro, Precordillera of Mendoza, Argentina. PalZ (Paläontologische Zeitschrift). $\quad$ https://doi.org/10.1007/s12542-0180403-y

Tortello, M.F. \& E.N.K. Clarkson. 2003. Ontogeny of the Early Ordovician olenid trilobite Jujuyaspis keideli Kobayashi from northwestern Argentina. Ameghiniana 40: 257-275.

Tortello, M.F. \& E.N.K. Clarkson. 2008. Ontogeny, structure and moulting of Parabolina frequens argentina (Kayser) (Trilobita, Olenidae) from the upper Cambrian of northwestern Argentina. Ameghiniana 35: 13-31.

Tortello, M.F. \& S.B. Esteban. 2003. Trilobites del Cámbrico Tardío de la Formación Lampazar (sierra de Cajas, Jujuy, Argentina). Implicancias bioestratigráficas y paleoambientales. Ameghiniana 40: 323-344.

Turner, J.C. 1960. Estratigrafía de la sierra de Santa Victoria y adyacencias. Boletín de la Academia Nacional de Ciencias (Córdoba) 41(2): 163-196.

Turner, J.C. \& R. Mon. 1979. Cordillera Oriental. In: J.C. Turner (ed.), Geología Regional Argentina, pp. 57-94, Academia Nacional de Ciencias, Córdoba.

Wahlenberg, G. 1818. Petrificata Telluris Svecanae. Nova Acta Regiae Societatis Scientarium Upsaliensis 8: 1-116.

Waisfeld, B.G. \& N.E. Vaccari. 2003. Trilobites. In: J.L. Benedetto (ed.), Ordovician fossils of Argentina, pp. 295-409, Secretaría de Ciencia y Tecnología, Universidad Nacional de Córdoba.

Waisfeld, B.G. \& N.E. Vaccari. 2008. Bioestratigrafía de trilobites del Paleozoico inferior de la Cordillera Oriental. In: B. Coira \& E.O. Zappettini (eds.), Geología y Recursos Naturales de la Provincia de Jujuy. Relatorio del 17º Congreso Geológico
Argentino, pp. 119-127, Asociación Geológica Argentina.

Westrop, S.R. 1995. Sunwaptan and Ibexian (Upper Cambrian-Lower Ordovician) trilobites of the Rabbitkettle Formation, Mountain River region, northern Mackenzie Mountains, northwest Canada. Palaeontographica Canadiana 12: 1-75.

Westrop, S.R., J.M. Adrain \& E. Landing. 2011. The Cambrian (Sunwaptan, Furongian) agnostoid arthropod Lotagnostus Whitehouse, 1936, in Laurentian and Avalonian North America: systematics and biostratigraphic significance. Bulletin of Geosciences 86: 569-594.

Whitehouse, F.W. 1936. The Cambrian of North-Eastern Australia. Memoirs of the Queensland Museum 11: 59-112.

Whittington, H.B. \& S.R.A. Kelly. 1997. Morphological terms applied to Trilobita. In: R.L. Kaesler (ed.), Treatise on Invertebrate Paleontology, Part $O$, Arthropoda 1. Trilobita, Revised, pp. 313-329, Geological Society of America and University of Kansas Press.

Zeballo, F.J. 2010. Bioestratigrafía de conodontes y graptolitos, y fósiles asociados, de las secuencias cambro-ordovícicas del flanco oriental de la Quebrada de Humahuaca, provincia de Jujuy, Argentina. Tesis Doctoral, Facultad de Ciencias Exactas, Físicas y Naturales, Universidad Nacional de Córdoba, 362 pp.

Zeballo, F.J. \& G.L. Albanesi. 2013. New conodont species and biostratigraphy of the Santa Rosita Formation (Upper Furongian-Tremadocian) in the Tilcara Range, Cordillera Oriental of Jujuy, Argentina. Geological Journal 48: 170-193.

Zeballo, F.J. \& M.F. Tortello. 2005. Trilobites del Cámbrico Tardío-Ordovícico Temprano del área de Alfarcito, Tilcara, Cordillera Oriental de Jujuy, Argentina. Ameghiniana 42: 127-142.

Żylińska, A. 2001. Late Cambrian trilobites from the Holy Cross Mountains, central Poland. Acta Geologica Polonica 51: 333-383.

Doi: 10.22179/REVMACN.20.601

Recibido: 16-IX-2018

Aceptado: 21-XI-2018 